\title{
DEVELOPMENT AND APPLICATION OF ALGORITHMS FOR SIMULATING TERRACES WITHIN SWAT
}

\author{
H. Shao, C. Baffaut, J. E. Gao, N. O. Nelson, K. A. Janssen, G. M. Pierzynski, P. L. Barnes
}

\begin{abstract}
Terraces have been proven to be an effective conservation practice for controlling high soil loss. In large hydrological programs such as the Soil and Water Assessment Tool (SWAT), terrace effects are simulated by adjusting the slope length and the USLE P-factor. In this study, a process-based terrace algorithm was developed and incorporated into SWAT (version 2009) to simulate the environmental effects of different kinds of terraces, i.e., normal and bench terraces. The terrace algorithm was activated at the hydrological response unit (HRU) level. Terrace description, storage effects, and the flow interaction between the terraces and the HRU were also introduced in the method. The modified SWAT model was evaluated using a four-year, six-plot event runoff and sediment data set with five years of plant yield data collected on a natural rainfall terraced field in southeast Franklin County, Kansas. Results indicated that the model's performance was satisfactory in simulating single and average plot runoff as well as average plot sediment yields, with Nash-Sutcliffe efficiencies always greater than 0.5 and often greater than 0.7. The model's performance was less consistent in simulating sediment yields from the no-till plots. The development and incorporation of the terrace algorithm provide a processbased alternative to the use of the P-factor in representing the effectiveness of terraces.
\end{abstract}

Keywords. Algorithm development, Erosion, Runoff, SWAT model, Terraces.

$\mathrm{T}$ errace practices are one of the oldest and most widely used means of saving water and controlling erosion all over the world (Dorren and Rey, 2004; Neibling and Thompson, 1992). Terracing has been an effective conservation practice for controlling high soil loss by decreasing slope length, slowing runoff, and causing settling of sediment and nutrients. Many field studies have been carried out to study runoff, sediment, and nutrient yields from terraces. Zeimen et al. (2006) studied the effects of no-till and different fertilizer and herbicide application methods for reducing sediment, nutrients, and herbicides on terraces in the central part of the U.S. Alberts et al. (1978) indicated that terraces were extremely effective in reducing runoff, sediment, and nitrogen and phos-

Submitted for review in November 2012 as manuscript number SW 10047; approved for publication by the Soil \& Water Division of ASABE in August 2013. Presented at the 2012 ASABE Annual Meeting as Paper No. 121341006

Mention of company or trade names is for description only and does not imply endorsement by the USDA. The USDA is an equal opportunity provider and employer.

The authors are Hui Shao, ASABE Member, Graduate Student, College of Resources and Environment, Northwest A\&F University, Yangling, Shaanxi, China; Claire Baffaut, ASABE Member, Research Hydrologist, USDA-ARS Cropping Systems and Water Quality Research Unit, Columbia, Missouri; Jian'en Gao, Professor, Northwest A\&F University, Institute of Soil and Water Conservation, Chinese Academy of Sciences and Ministry of Water Resources, Yangling, Shaanxi, China; Nathan O. Nelson, Associate Professor, Keith A. Janssen, Retired Professor, and Gary M. Pierzynski, Professor, Department of Agronomy, Kansas State University, Manhattan, Kansas; Philip L. Barnes, ASABE Member, Associate Professor, Department of Biological and Agricultural Engineering, Kansas State University, Manhattan, Kansas. Corresponding author: Claire Baffaut, $241 \mathrm{Ag}$ Engineering Building, University of Missouri, Columbia, MO 65211; phone: 573-882-1114, ext. 315; email: Claire.Baffaut@ars.usda.gov. phorus losses from a corn-cropped watershed located in southwest Iowa in the U.S. In the Loess Plateau of China, Shi (1996) reported that the combined use of bench terraces and forest planting reduced runoff by $20 \%$ and sediment by $60 \%$ under a rainfall intensity of $1.03 \mathrm{~mm} \mathrm{~min}^{-1}$ compared to fallow land. Wang et al. (2011) indicated that a reverseslope terrace installed on a natural rainfall experiment plot in southwest China could reduce runoff and sediment yield by $65.3 \%$ and $80.7 \%$, respectively.

Simulation of terraces has been performed in a variety of models, including the Soil and Water Assessment Tool (SWAT) watershed-scale water quality model (Arnold and Fohrer, 2005; Gassman et al., 2007; Williams et al., 2008; Arnold et al., 2012) and the Agricultural Policy/ Environmental eXtender (APEX) farm-scale environmental model (Williams et al., 2008; Gassman et al., 2010). Traditionally, accounting for terrace impacts on runoff, sediment, and nutrient yields in models such as SWAT and APEX has relied on empirical approaches involving adjustment of key input variables such as the runoff curve number $(\mathrm{CN})$, slope length, and Universal Soil Loss Equation (USLE) control practice factor (USLE P-factor) (Arabi et al., 2008; Waidler et al., 2011; Maski et al., 2008; Bracmort et al., 2006). These empirical approaches draw on original USLE research (Wischmeier and Smith, 1978; Laflen and Moldenhauer, 2003) and to date have served as the only practical way to represent terraces in most water quality and environmental models. However, these empirical methods have several limitations because the effects caused by land shape changes, due to the installation of terraces, can only be approximately reflected by this type of approach. For example, the water trapping and storage on the terrace, which leads to extra infiltration and evaporation as well as sediment and 
nutrients settling, are not well simulated by these empirical methods. Other problems arise due to the use of such empirical methods when the cropping and management practices used on terraces are different from other subareas of the cropped landscape, which can be difficult to represent in models such as SWAT.

As a consequence of the lack of representation of specific terrace processes in simulation models, Van Dijk and Bruijnzeel (2004a, 2004b) developed an event-based model that simulated runoff and sediment load from different segments and the whole unit of bench terraces. The model's performance was satisfactory, and their efforts indicated the feasibility of a process-based simulation method. Shao et al. (2012) developed process-based algorithms and showed that they were a feasible alternative for simulating terrace effects on soil erosion. However, the model reported by Van Dijk and Bruijnzeel (2004a, 2004b) was for field-scale simulation, and the algorithms developed by Shao et al. (2012) were only tested with a spreadsheet program (MS Excel 2010), whereas computer-based watershed models are needed in order to simulate the long-term continuous effects of terraces at the watershed scale. Thus, this study specifically focuses on finalizing the algorithm developed by Shao et al. (2012) and incorporating it into SWAT. The SWAT model was selected because of its use of readily available input data, process-based simulation algorithms, and its open source code (Easton et al., 2008). Many previous successful modifications of the SWAT model, conducted by developers all over the world, have contributed to the model's widespread use and flexibility (e.g., Easton et al., 2008; Gassman et al., 2007; Jeong et al., 2011a, 2011b; Moriasi et al., 2009, 2011).

Thus, the overall objective of this study was to develop and test a process-based algorithm to directly simulate the environmental effects of terraces and incorporate the algorithm into the SWAT model. Specific study objectives were to (1) develop a process-based algorithm to simulate sediment and runoff from terraced landscapes, (2) develop a mechanism to describe physical characteristics of terraces in SWAT at the HRU level, and (3) incorporate and evaluate the new process-based terrace algorithm in SWAT.

\section{Algorithm Development MAIN TYPES OF TERRACES}

Different criteria have been used to classify terraces according to their main function, the construction process, the size of the terrace base, and the shape (Dorren and Rey, 2004). The proposed algorithm targets two commonly used terraces on agricultural land: normal terraces (fig. 1) built in relatively flat terrain and very common in the U.S., and bench terraces (fig. 2) built on steeper ground and common in China and Asia. A terrace unit usually consists of three kinds of segments: the undisturbed segment, two risers (cutslope), and the bed (frontslope) (fig. 1). Each of these segments is defined by the average slope length and average slope steepness. The undisturbed segment in some terraces can be missing, e.g., bench terraces built in China often contain only riser and bed segments (fig. 2).

\section{DESIGN AND INCORPORATION OF TERRACE ALgORITHMS IN SWAT}

The principal objective of a terrace (either normal or bench terrace) is to reduce the sediment yield from a slope (Dorren and Rey, 2004). Building a terrace splits the original slope into several terrace units and decreases the original slope length. It can create a storage volume in which slower water promotes sediment and nutrient settling. Additionally, water storage in the terrace also results in more evaporation from the free water surface and more infiltration, thus reducing runoff.

Since terraces can have complex influences on watershed hydrological processes, the terrace algorithms were designed to be integrated into SWAT at the hydrological response unit (HRU) level. The HRU is the basic unit in SWAT for simulating hydrological processes and pollutant transport (i.e., runoff, erosion, groundwater, nitrogen and phosphorus loads, and plant growth). In this algorithm, the terraced area acts as a "sub-HRU" area with its own shape and soil system (fig. 3).

In the terrace simulation process, the algorithm first simulates the water, sediment, nitrogen $(\mathrm{N})$, and phosphorus $(\mathrm{P})$ yields, soil $\mathrm{N}$ and $\mathrm{P}$ dynamics, and plant growth and management on each terrace segment. Sediment and $N$ and $P$ settling as well as infiltration and evaporation of the stored water are simulated after loading all the runoff, sediment, $\mathrm{N}$, and $\mathrm{P}$ from each segment to the terrace storage volume. Two kinds of outflow (drainage and overland outflow) are considered in this algorithm. The drainage outflow can be drained either to a secondary channel (i.e., linked to a grass waterway, pond, or wetland) or to the main stream. The overland outflow only happens during large events when the generated surface runoff exceeds the terrace storage capacity. As shown in figure 3, the runoff generated from the unterraced area is allowed to flow into the terraced area and contribute to the terrace processes. The soil system in the terrace is initially the same as that of the HRU but is processed separately to allow differences in soil moisture and $\mathrm{N}$ and $\mathrm{P}$ content. The terraced and unterraced areas share the same groundwater system. Specific equations and methods used in the algorithm are discussed in the following sections.

The terrace algorithm code was developed and incorporated in SWAT version 2009 (SWAT2009, release 488) for HRUs that have terraces. The terraced area in one HRU may contain several terrace units that are assumed to have the same geometric characteristics. The detailed processes of the terrace algorithm in SWAT are shown in figure 4.

\section{TERRACE GEOMETRY}

Typical cross-sections are assumed to calculate the storage volume and water surface area for normal and bench terraces. As shown in figure 5, the water volume held or stored by a normal terrace is assumed to have the shape of a triangular prism. The algorithm for computing the maximum storage volume and maximum free water surface area of a normal terrace are described in equation 1 and 2, respectively. These equations are inferred based on the assumptions that both riser segments on one terrace unit have 

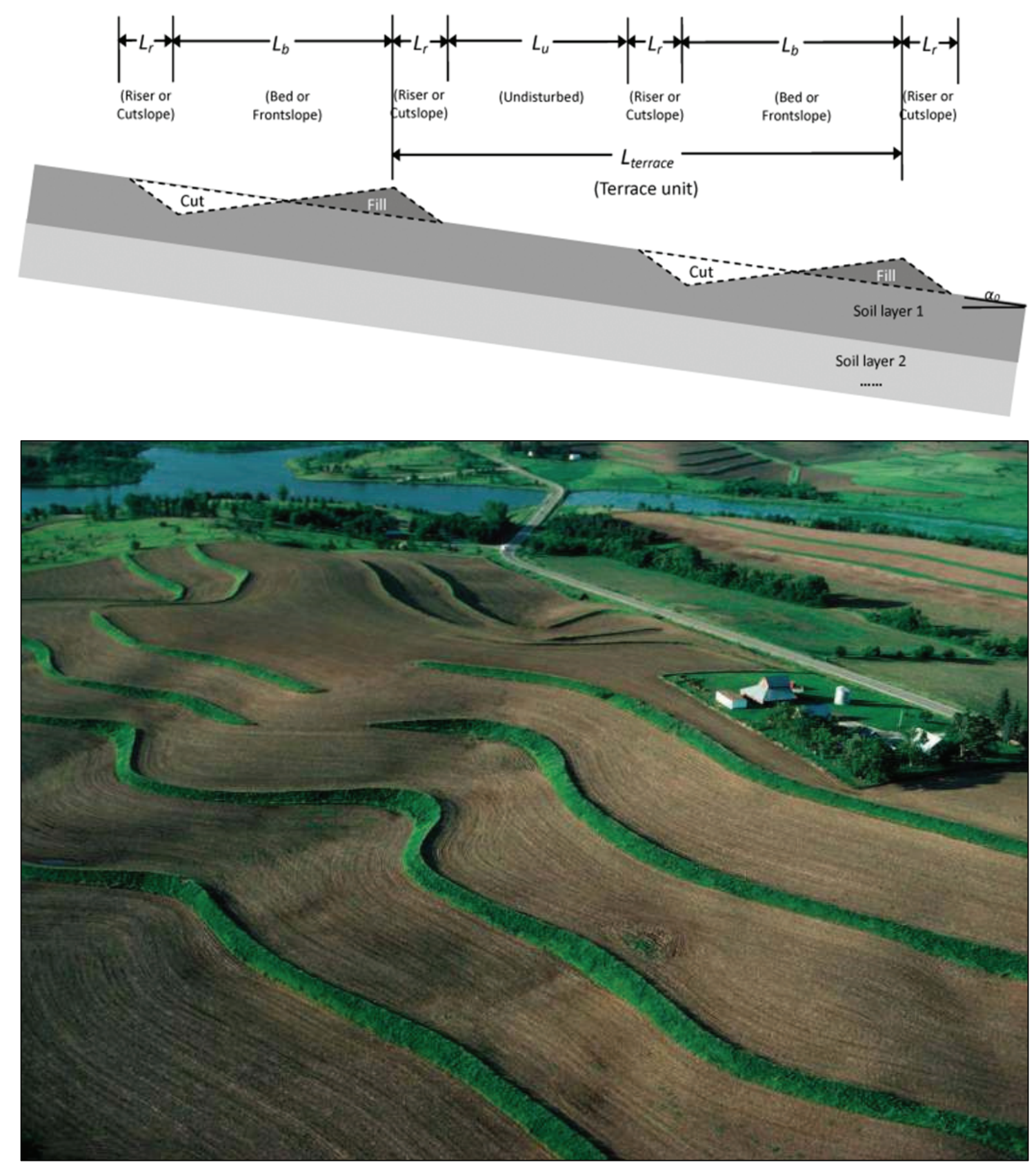

Figure 1. Sketch description (top) and photo (bottom) of normal terraces in Iowa (photo by Tim McCabe).

the same slope steepness and that the cut and fill soil volumes are equal:

$$
\begin{aligned}
V_{m x}= & \frac{N_{t}}{2} \cdot\left(L_{b} \cdot \tan \alpha_{b}\right)^{2} \\
& \cdot\left(\tan ^{-1}\left(\alpha_{b}\right)+\tan ^{-1}\left(\alpha_{r}\right)\right) \cdot W \\
S A_{m x} & =\frac{N_{t}}{10000} \cdot L_{b} \cdot \tan \alpha_{b} \\
& \cdot\left(\tan ^{-1}\left(\alpha_{b}\right)+\tan ^{-1}\left(\alpha_{r}\right)\right) \cdot W
\end{aligned}
$$

(2) where Round is the function of rounding to the nearest integer, area $_{\text {trc }}$ is the area of the whole terraced area (ha), $L_{u}$ is the slope length of the undisturbed segment (m), and $L_{r}$ is the slope length of the riser and is either user-specified or calculated using equation 4 : where $V_{m x}$ is the maximum water storage of the terrace $\left(\mathrm{m}^{3}\right.$ $\left.\mathrm{H}_{2} \mathrm{O}\right), L_{b}$ is the slope length of the bed in one terrace (m), $a_{b}$ and $a_{r}$ are the angle of the bed and riser of the terrace, $W$ is the average contour length of the terrace unit (m), and $S A_{m x}$ is the maximum water surface area of the terrace (ha). $N_{t}$ is the number of terrace units in one HRU and is estimated with equation 3 :

$$
N_{t}=\text { Round }\left(\frac{10000 \cdot \text { area }_{t r c}}{\left(L_{u}+2 \cdot L_{r}+L_{b}\right) \cdot W}\right)
$$



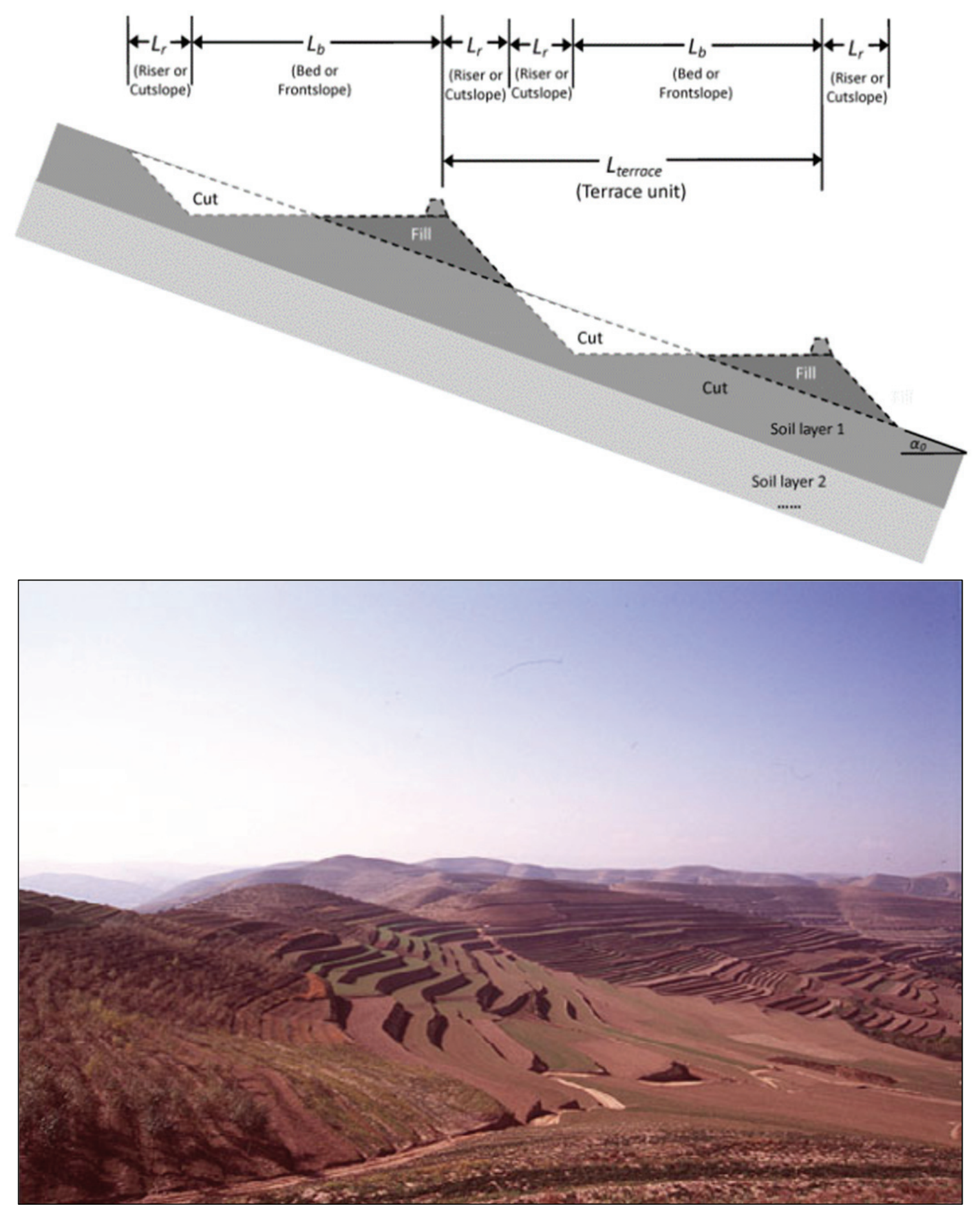

Figure 2. Sketch description (top) and photo (bottom) of bench terraces in China (photo by UN World Food Program).

$$
L_{r}=\frac{L_{b}}{2} \cdot \frac{\cos \alpha_{r}}{\cos \alpha_{b}} \cdot \frac{\sin \left(\alpha_{b}+\alpha_{0}\right)}{\sin \left(\alpha_{r}-\alpha_{0}\right)}
$$

where, in addition to the previously defined variables, $a_{0}$ is the slope steepness of the original land $\left(\mathrm{m} \mathrm{m}^{-1}\right)$.

For bench terraces, the slope steepness of the bed segment is set as $0 \%$ and the ridge height is required, as shown in figure 6 . The program simplifies the storage volume of a bench terrace as a cuboid. Equations 5 and 6 are used for calculating the maximum storage volume and maximum surface area in a bench terrace:

$$
\begin{gathered}
V_{m x}=N_{t} \cdot L_{b} \cdot H_{t} \cdot W \\
S A_{m x}=N_{t} \cdot L_{b} \cdot W
\end{gathered}
$$

where $H_{t}$ is the ridge height in the terrace bed segment (m) and is a user-specified input parameter.

The free water surface area is needed for calculating evaporation and infiltration in the terrace. Its value is a function of the volume of water held in the terrace, which is 


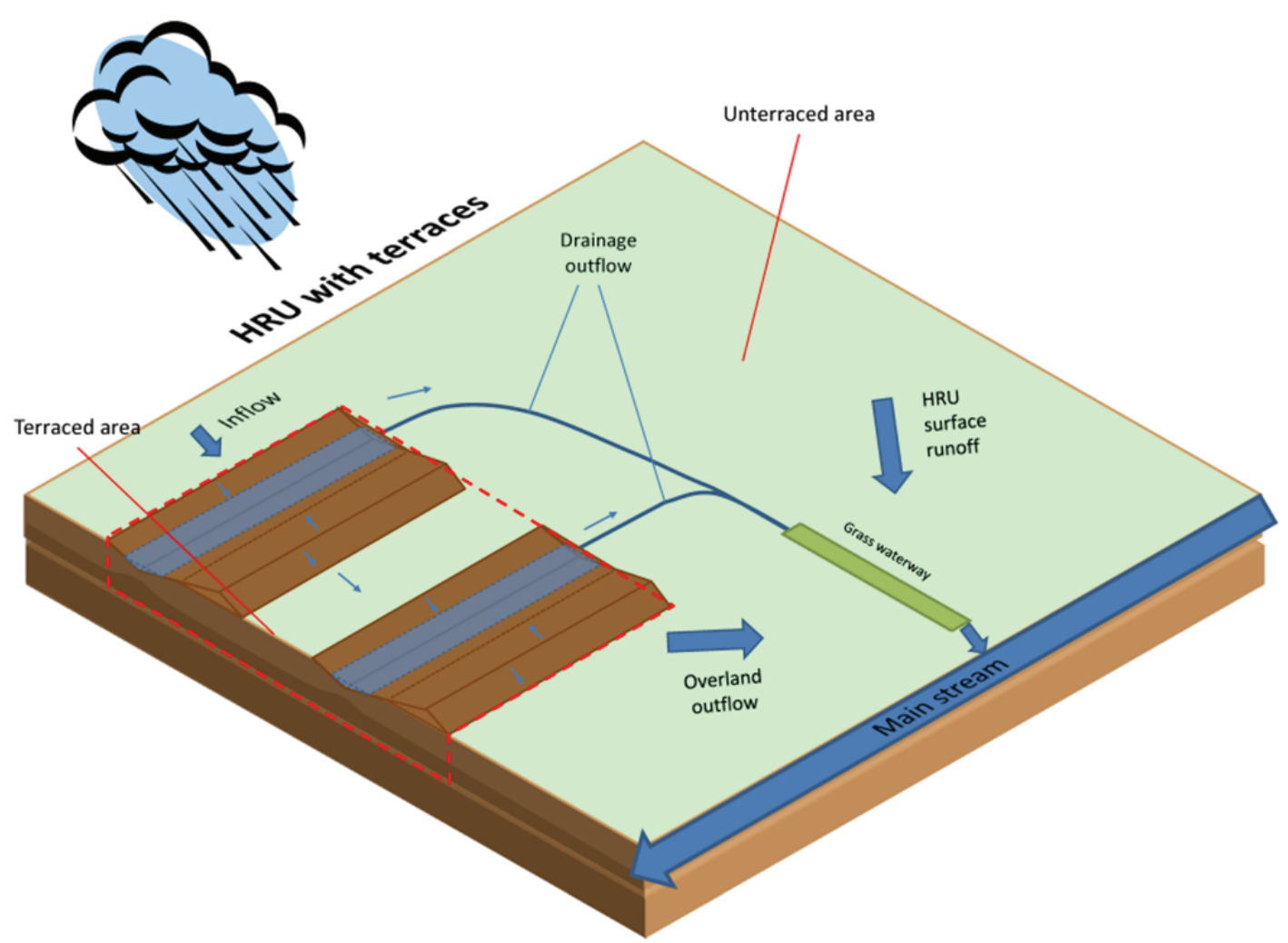

Figure 3. Sketch map of an HRU in SWAT with a terraced area.
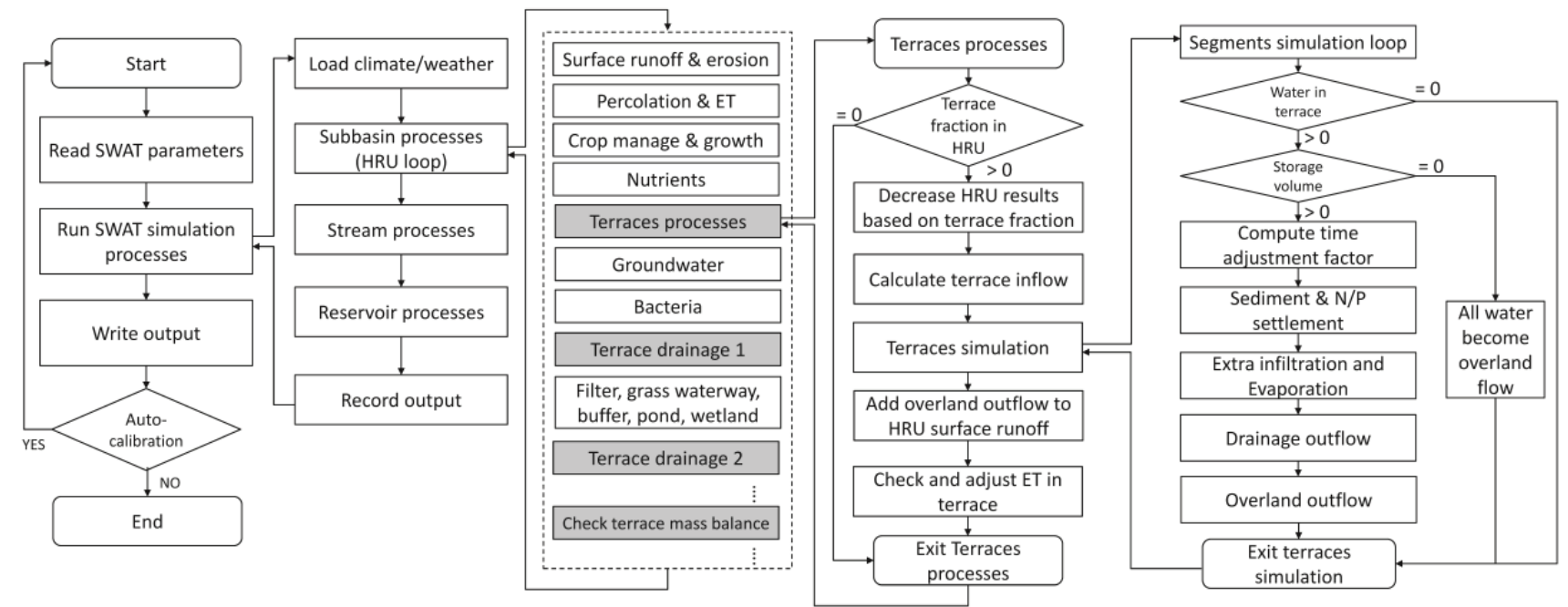

Figure 4. Flowchart of the terrace simulation algorithm in SWAT.

calculated before the estimation of infiltration and evaporation. Equations 7 and 8 are used for estimating the free water surface area based on geometric relationships:

For normal terrace: $\quad S A(t)=S A_{m x} \cdot\left(\frac{V_{s t l}+V(t)}{V_{m x}}\right)^{0.5}$

For bench terrace: $\quad S A(t)=S A_{m x}$

where $S A(t)$ is the instantaneous free water surface area (ha), $V_{s t l}$ is the volume of settled sediment in the terrace channel $\left(\mathrm{m}^{3}\right)$, and $V(t)$ is the instantaneous water volume stored in the terrace $\left(\mathrm{m}^{3} \mathrm{H}_{2} \mathrm{O}\right)$.

\section{Segment Simulation}

All the simulation algorithms for the segment processes are originally from SWAT2009 and are described in the corresponding theoretical documentation (Neitsch et al., 2011). The runoff prediction method uses the daily SCS curve number method. The daily curve number, which is used for predicting daily runoff from each slope segment, is adjusted as a function of current soil moisture or plant evapotranspiration. 


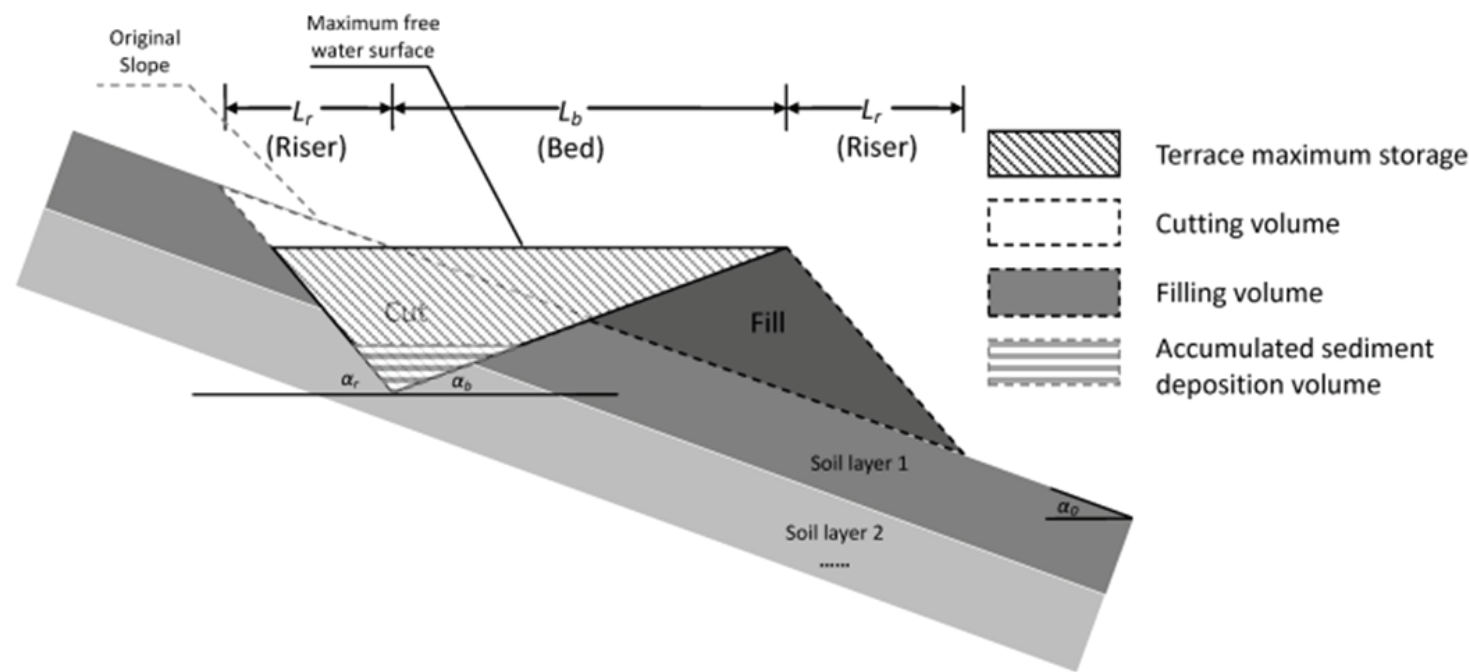

Figure 5. Cross-section of a normal terrace.

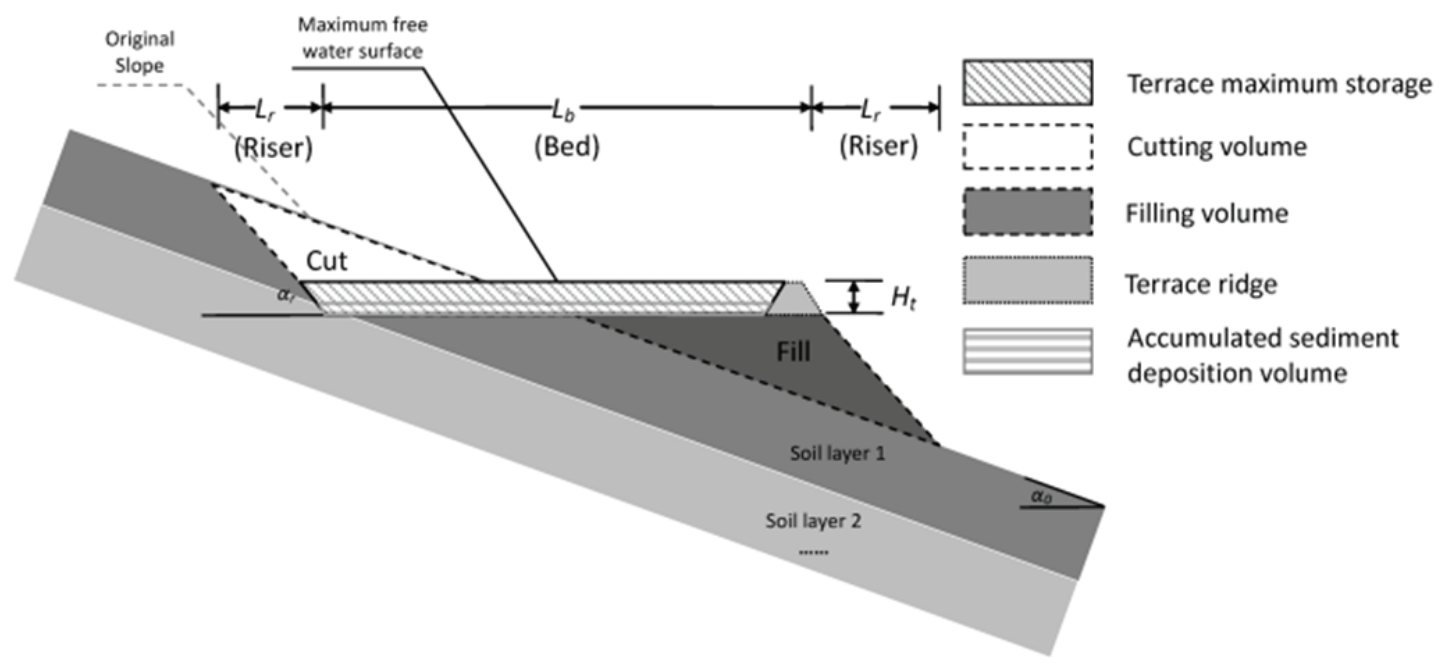

Figure 6. Cross-section of a bench terrace.

In calculating the runoff and peak runoff rate, one main difference between the terrace segment algorithm and the original method at the HRU level is that potential transmission losses from ephemeral channels are not simulated in terraces. The purpose of a well-built terrace is to decrease the slope length, which reduces the chance of ephemeral channel formation.

The Modified Universal Soil Loss Equation (MUSLE) is used for predicting the erosion (Williams, 1995). Compared to the Universal Soil Loss Equation (USLE), the modified version uses a runoff factor instead of a rainfall factor in predicting erosion. It also allows the model to predict erosion for each runoff event.

Both mineral and organic $\mathrm{N}$ and $\mathrm{P}$ loss in runoff, lateral flow, and sediment from each terrace segment are calculated using the algorithms adapted from SWAT2009. All the soil $\mathrm{N}$ and $\mathrm{P}$ processes simulated in SWAT are incorporated in the terrace segment simulation. Selected management operations are also incorporated into the segment simulation, including planting, three types of fertilization (auto, manual, and continuous), two types of irrigation (auto and manual), tillage, kill operation, and three harvest practices (harvest only, harvest and kill, and harvest grain). It is assumed that there is no urban area on terraces. Specific equations for these processes are described in the SWAT2009 theoretical documentation.

\section{TERRACE Storage EFFECT}

After the runoff and sediment simulation on each terrace segment, all the yields (runoff, sediment, N, and P) are added into the terrace storage volume. Once the water is held in the terrace storage, terrace storage effects are simulated; these include evaporation from the free water surface, infiltration through the terrace bed, and settling of sediment, N, and $\mathrm{P}$. The detailed algorithms for simulating these effects are listed below.

\section{Sub-daily Adjustment Factor}

During small runoff events, the stored water in the terrace can be drained out of the terrace in less than one day though 
a channel running along the terrace to a grassed waterway or lined channel or through an underground pipe leading to an outlet in the receiving stream. The terrace storage effects such as infiltration through the terrace bed or evaporation would be overestimated if using the $24 \mathrm{~h}$ simulation period, e.g., a permeable soil in the terrace may cause too much infiltration over $24 \mathrm{~h}$ if a sub-daily simulation period is not considered. Therefore, a sub-daily time adjustment factor is introduced into the model to describe the proportion of the day during which these terrace storage processes occur.

The time factor is equal to the fraction of day required to drain the stored water out of the terrace. It is calculated using the open-channel flow equation (eq. 9) combined with the relationship between water volume and depth for both normal terraces and bench terraces (eq. 10):

$$
\begin{gathered}
Q(t)=-\frac{d V(t)}{d t}=\frac{1}{n_{t r c b}} \cdot A_{c h} \cdot R_{c h}^{2 / 3} \cdot s l p_{c h}^{1 / 2} \\
V(t) \propto \begin{cases}H^{2}(t) & \text { for normal terrace } \\
H(t) & \text { for bench terrace }\end{cases} \\
-\frac{d V(t)}{d t}= \begin{cases}k \cdot V^{4 / 3}(t) & \text { for normal terrace } \\
k \cdot V^{5 / 3}(t) & \text { for bench terrace }\end{cases} \\
T=\left\{\begin{array}{l}
\frac{3}{k} \cdot\left[V^{-1 / 3}(T)-V_{0}^{-1 / 3}\right. \\
\frac{3}{2 \cdot k} \cdot\left[V^{-2 / 3}(T)-V_{0}^{-2 / 3}\right.
\end{array}\right] \text { for normal terrace }
\end{gathered}
$$

where $n_{\text {trcb }}$ is the Manning's $\mathrm{n}$ of the terrace bed segment, $A_{c h}$ is the discharge section area $\left(\mathrm{m}^{2}\right), R_{c h}$ is the hydraulic radius of the discharge section $(\mathrm{m}), s l p_{c h}$ is the slope steepness of the drainage channel, $t$ is instantaneous time (d), $V_{0}$ water volume stored in the terrace after receiving runoff from all terrace segments $\left(\mathrm{m}^{3} \mathrm{H}_{2} \mathrm{O}\right)$, and $H(t)$ is the instantaneous depth of water from the lowest point to the free water surface in the terrace $(\mathrm{m})$. The cross-section area $\left(A_{c h}\right)$ and hydraulic radius $\left(R_{c h}\right)$ are expressed as a function of the terrace geometry and the water depth $H$ and inserted into equation 9 to produce equation 11 . The constant $k$ is the declining rate of drainage and is related to the characteristics of the terrace's channel. $T$ is the total drainage time (d), and $V(T)$ is the remaining water volume at the end of drainage $\left(\mathrm{m}^{3} \mathrm{H}_{2} \mathrm{O}\right)$; we assume that there will always be some water left in the terrace at the end of an event, about $1 \%$ of the daily drainage capacity.

Solution of equation 11 is shown in equation 12 . The assumptions that drainage will stop or not start when the water amount is less than $1 \%$ of the daily drainage capacity and that $99 \%$ of the drainage capacity can be drained out of the terrace within $24 \mathrm{~h}$ serve in calculating $k$ and $V(T)$ in equation 12 and result in equation 13 to calculate the subdaily adjustment factor (tfactor). This adjustment factor is set to 1.0 if it is less than 0 or larger than 1.0:

$$
\text { tfactor }=\frac{T}{1 \text { day }}
$$

For normal terrace:

$$
\text { tfactor }=\frac{4.64 \cdot\left(\text { area }_{t r c} \cdot V_{d r m x}\right)^{-1 / 3}-V_{0}^{-1 / 3}}{3.64 \cdot\left(\text { area }_{t r c} \cdot V_{d r m x}\right)^{-1 / 3}}
$$

For bench terrace:

$$
\text { tfactor }=\frac{21.54 \cdot\left(\text { area }_{t r c} \cdot V_{d r m x}\right)^{-2 / 3}-V_{0}^{-2 / 3}}{20.54 \cdot\left(\text { area }_{t r c} \cdot V_{d r m x}\right)^{-2 / 3}}
$$

where tfactor is the sub-daily adjustment factor $\left(\mathrm{d} \mathrm{d}^{-1}\right.$, range from 0 to 1$)$, and $V_{d r m x}$ is the maximum daily drainage volume $\left(\mathrm{m}^{3} \mathrm{H}_{2} \mathrm{O} \mathrm{d}^{-1} \mathrm{ha}^{-1}\right)$.

\section{Water Storage Effect}

The volume of water lost to extra evaporation on a given day is calculated as a function of the leaf area index of the bed segment, the potential evaporation, and the sub-daily adjustment factor (Du et al., 2005; Neitsch et al., 2011). The extra infiltration through the bottom of the terrace storage area on a given day is calculated by considering the water content of the soil profile in the bed segment and the sub-daily adjustment factor, which is also adopted from SWAT2009 (Du et al., 2005; Neitsch et al., 2011). Water lost from the terrace storage by infiltration is added to the soil profile in the bed segment.

\section{Sediment and Nutrients Settling}

After runoff is loaded into the terrace storage, the suspended sediment particles in that water settle due to slower flow velocity. The equilibrium concentration method used in SWAT for calculating sediment settling in potholes and reservoirs is adopted for terraces with consideration of the sub-daily adjustment factor (Neitsch et al., 2011). The settled sediment is deposited in the terrace and reduces the maximum available volume of terrace storage. $\mathrm{N}$ and $\mathrm{P}$ also settle in the stored water of the terrace. The settling is estimated using the apparent settling velocity method with consideration of the sub-daily adjustment factor (Neitsch et al., 2011; Panuska, 1999).

\section{Terrace Outflow}

Two types of surface outflow from a terrace can occur. One is controlled drainage outflow using a subsurface tile drain with an inlet, a lined channel, or a grass waterway. The other is overland flow that overtops the terrace ridge during large storm events. The drainage output can lead to channel erosion in the terrace, which is also incorporated into SWAT.

\section{Channel Erosion}

Channel erosion caused by drainage flow inside the terrace is simulated when the maximum potential sediment concentration in peak flow exceeds the current concentration. The peak channel velocity is calculated using the Manning equation, and the maximum sediment concentration is estimated using the simplified Bagnold method (Neitsch et al., 2011).

Channel degradation is a function of the difference between current and maximum potential sediment concentra- 
tion and also considers soil erodibility, soil cover, and travel time (Narasimhan et al., 2007; Narasimhan et al., 2010; Neitsch et al., 2011). One difference compared to the original SWAT code is that the terrace algorithm proposed here does not simulate the deposition process because that is already considered in the sediment settling. The sediment eroded from the channel is directly added to the sediment load out of the terrace. Similar to the current SWAT model (Narasimhan et al., 2010), degradation is proportional to travel time. However, the assumption that maximum potential sediment concentration could be met after traveling one hour instead of one day is used in terrace simulation because terrace channels are typically much shorter than reach channels.

The $\mathrm{N}$ and $\mathrm{P}$ attached to the soil eroded through channel degradation are also added to the $\mathrm{N}$ and $\mathrm{P}$ loads out of the terrace. It is assumed that they come from the bed segment and have the same concentration as the first layer of the bed soil (Neitsch et al., 2011).

\section{Drainage Outflow}

The amount of released water from drainage outflow is controlled by two parameters: the normal storage depth and the maximum drainage rate. There is no drainage outflow unless the water stored in the terrace exceeds the minimum drainage trigger depth (the normal storage depth). The maximum drainage rate represents the maximum amount of water that the drainage system can release from the terrace each day. Equations 14 to 16 are used for calculating the drainage outflow:

For normal terrace:

$$
\begin{gathered}
V_{d r}=\operatorname{Min}\left[V-5 \cdot\left(H T_{\text {norm }}-H T_{\text {stl }}\right)\right. \\
\left.\cdot\left(S A_{s t l}+S A_{\text {norm }}\right),\left(V_{d r m x} \cdot \text { area }_{\text {trc }}\right)\right] \\
S A_{\text {norm }}=S A_{m x} \cdot \frac{H T_{\text {norm }}}{H T_{m x}}
\end{gathered}
$$

For bench terrace:

$$
\begin{gathered}
V_{d r}=\operatorname{Min}\left[V-5 \cdot\left(H T_{\text {norm }}-H T_{s t l}\right)\right. \\
\left.\cdot S A_{m x},\left(V_{d r m x} \cdot \text { area }_{t r c}\right)\right]
\end{gathered}
$$

where $V_{d r}$ is the amount of water in drainage outflow $\left(\mathrm{m}^{3}\right.$ $\mathrm{H}_{2} \mathrm{O}$ ), $H T_{\text {norm }}$ is the minimum depth of water on the terrace to trigger the drainage $\left(\mathrm{mm} \mathrm{H}_{2} \mathrm{O}\right), H T_{\text {stl }}$ is the depth of settled sediment (mm), $S A_{s t l}$ is the surface area of settled sediment (ha), $S A_{\text {norm }}$ is the surface area at trigger depth (ha), and $H T_{m x}$ is the maximum depth of stored water on the terrace from the bottom of the channel to the top of the terrace ridge $(\mathrm{mm})$.

The N, P, and sediment suspended in the terrace water are also released with drainage outflow. The assumption that sediment, $\mathrm{N}$, and $\mathrm{P}$ are fully mixed in the stored water serves in calculating their concentrations in the drainage outflow.

\section{Overland Outflow}

In most cases, a terrace and its drainage system are designed to avoid being overtopped by the stored volume. However, some very intense storms may cause runoff to exceed the maximum terrace storage volume. This excess runoff becomes the overland outflow from the terrace and is added to the surface flow of the HRU. As with the drainage outflow, the sediment, $\mathrm{N}$, and $\mathrm{P}$ are also transported out of the terrace with overland flow.

\section{Model Evaluation}

A four-year (2001 to 2004) data set consisting of six large plots, with crop yield data and 36 runoff and sediment events for each plot, was used to test the accuracy of surface runoff and sediment yields estimated with the new version of SWAT.

\section{Study AREA AND SAMPle Collection}

The field experiment was performed in a 4.06 ha natural rainfall runoff terraced field containing six separate terraces ranging in area from 0.39 to 1.46 ha. The field is located in southeast Franklin County, Kansas, in the Upper Marais des Cygnes basin (HUC 10290101), as shown in figure 7. Average annual precipitation (1971 to 2000, Ottawa, Kans.) was $970 \mathrm{~mm}$, with 46\% falling between April and July. Annual rainfall for the study period was recorded on-site: $940 \mathrm{~mm}$ (2001), $644 \mathrm{~mm}$ (2002), $746 \mathrm{~mm}$ (2003), and $1,075 \mathrm{~mm}$ (2004). Three tillage and fertilizer management systems were applied in duplicate to a grain sorghum and soybean crop rotation from 2000 to 2004 (fig. 7). Fall chisel tillage and spring cultivation (marked as TILL) were used in plots 5 and 6 . No-till with surface-broadcast spring fertilizer (marked as NT/SB) was applied in plots 4 and 8, and no-till with deep-banded fertilizer applications (NT/DB) was used for plots 2 and 7.

Event runoff and sediment were measured during the growing season (April through October) for each plot. Samplers (6700, Isco, Inc., Lincoln, Neb.) collected one flow-weighted water sample for each runoff event. Runoff was measured at the end of each plot terrace channel by $90^{\circ}$ V-notch weirs (Grant and Dawson, 2001). Sediment concentration in the runoff was measured by filtering $100 \mathrm{~mL}$ of water through pre-weighed $0.45 \mu \mathrm{m}$ pore size filter paper with assistance of a vacuum pump. These filter papers were dried in an oven at approximately $105^{\circ} \mathrm{C}$ for $24 \mathrm{~h}$ and then weighed to determine sediment mass (Csuros, 1997; Maski et al., 2008). Annual crop yield was obtained from 2000 to 2004 . Every two plots with the same management were set as a group for measuring crop yield in bushels per acre, e.g., the crop yields of plots 5 and 6 (TILL) were measured together.

\section{DATA SOURCES}

Daily time series of maximum and minimum temperature, relative humidity, solar radiation, and wind speed (2000 to 2004) served as the weather input data, which were measured at the nearest weather station (about $20 \mathrm{~km}$ away) at Ottawa, Kansas (Maski et al., 2008). The precipitation data included data measured on-site during the growing season (April through October) and were supplemented with data from the Ottawa weather station during the winter months.

The soil type and physical data were obtained from the 


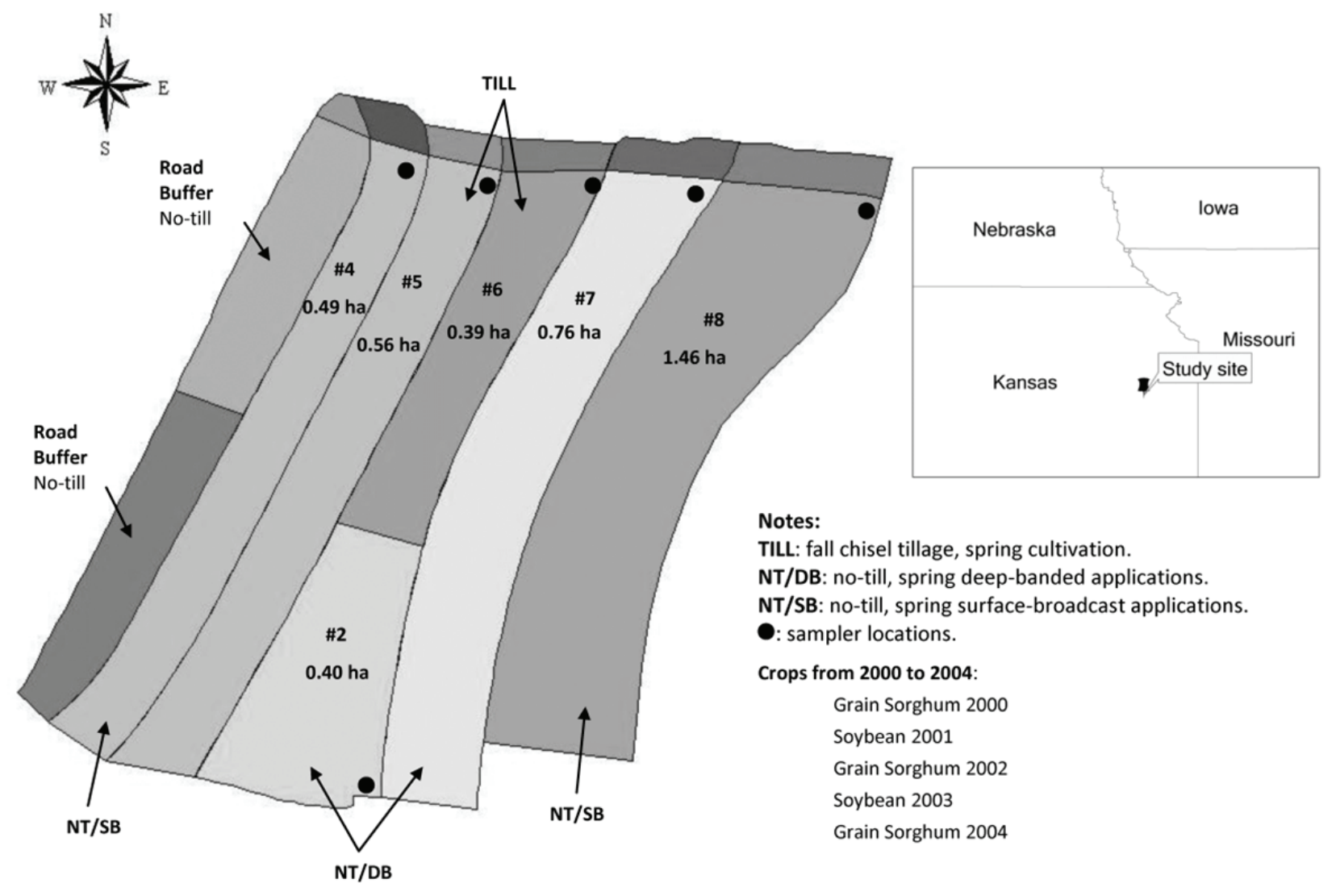

0.05

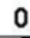

0.05 Miles

Figure 7. Layout of study area with six individual terrace plots (after Maski et al., 2008).

Table 1. Initial soil properties used in the SWAT model of the terraced field in Franklin County, Kansas.

\begin{tabular}{|c|c|c|c|c|c|c|c|c|}
\hline \multirow[b]{2}{*}{ Soil Property } & \multicolumn{4}{|c|}{ Eram Lebo silty clay loam (EL, plots 4, 5, and 6) } & \multicolumn{4}{|c|}{ Summit silty clay loam (SUM, plots 2, 7, and 8) } \\
\hline & Layer 1 & Layer 2 & Layer 3 & Layer 4 & Layer 1 & Layer 2 & Layer 3 & Layer 4 \\
\hline Depth $(\mathrm{mm})$ & 178 & 356 & 711 & 914 & 203 & 330 & 1016 & 1524 \\
\hline SOL_BD $\left(\mathrm{Mg} \mathrm{m}^{-3}\right)$ & 1.45 & 1.50 & 1.50 & 1.50 & 1.38 & 1.50 & 1.48 & 1.48 \\
\hline SOL_AWC & 0.15 & 0.10 & 0.10 & 0.16 & 0.18 & 0.14 & 0.14 & 0.14 \\
\hline SOL_K $\left(\mathrm{mm} \mathrm{h}^{-1}\right)$ & 10.8 & 3.6 & 3.6 & 3.6 & 10.8 & 10.8 & 3.6 & 3.6 \\
\hline SOL $\mathrm{CBN}(\%)$ & 2.0 & 1.0 & 1.0 & 0.5 & 3.0 & 2.5 & 1.5 & 1.0 \\
\hline CLAY (\%) & 34 & 45 & 45 & 38 & 34 & 36 & 45 & 42 \\
\hline SILT (\%) & 60 & 45 & 45 & 52 & 56 & 54 & 47 & 50 \\
\hline SAND (\%) & 6 & 10 & 10 & 10 & 10 & 10 & 8 & 8 \\
\hline ROCK (\%) & 0 & 0 & 0 & 0 & 0 & 0 & 0 & 0 \\
\hline SOL_ALB & 0.01 & 0.03 & 0.03 & 0.08 & 0.01 & 0.01 & 0.01 & 0.03 \\
\hline USLEE K & 0.37 & 0.37 & 0.37 & 0.37 & 0.37 & 0.37 & 0.37 & 0.37 \\
\hline SOL_E $\bar{E} C$ & 0 & 0 & 0 & 0 & 0 & 0 & 0 & 0 \\
\hline
\end{tabular}

Soil Data Explorer of USDA Natural Resources Conservation Service (http://websoilsurvey.nrcs.usda.gov/app/Web SoilSurvey.aspx; accessed 19 June 2012). Two soil map units were identified within the study area: Summit silty clay loam (SUM) on plots 2, 7, and 8, and Eram Lebo silty clay loam (EL) on plots 4, 5, and 6 . The soil data used in the model are listed in table 1 .

The topography data used in the model are listed in table 2. GPS data points at a distance of $50 \mathrm{~m}$ were used to calculate the average slope steepness of each plot and the terrace channel. The slope length of the bed segment and the slope steepness of both the bed and riser of each plot were measured in August 2012. The average total slope length (from the top ridge to the lower ridge), the terrace width, and the channel length of each plot were measured using the measurement tool in Google Earth with images from the USDA Farm Service Agency taken on 19 August 2010. These images were generated under the National Agriculture Imagery Program (NAIP); they have a $1 \mathrm{~m}$ ground sample distance and a required $6 \mathrm{~m}$ accuracy relative to true ground (Mathews, 2012). The slope length of the riser was calculated using equation 4.

Grain sorghum was grown in all plots in 2000 , followed by soybean in 2001, grain sorghum in 2002, soybean in 
Table 2. Topography data used in the modified SWAT model of the terraced field in Franklin County, Kansas.

\begin{tabular}{|c|c|c|c|c|c|c|c|c|c|}
\hline \multirow[b]{2}{*}{ Plot } & \multicolumn{3}{|c|}{ Slope Steepness (\%) } & \multicolumn{3}{|c|}{ Slope Length (m) } & \multicolumn{2}{|c|}{ Channel } & \multirow{2}{*}{$\begin{array}{c}\text { Terrace Width } \\
(\mathrm{m})\end{array}$} \\
\hline & Original & Bed & Riser & Total & Bed & Undisturbed $^{[\mathrm{a}]}$ & $L(\mathrm{~m})$ & $\alpha(\%)$ & \\
\hline 2 & 4.9 & 7.0 & 19.2 & 40.0 & 5.1 & 30.8 & 95.0 & 0.3 & 95.0 \\
\hline 4 & 6.6 & 10.5 & 12.2 & 20.0 & 2.8 & 8.8 & 240.0 & 0.1 & 240.0 \\
\hline 5 & 9.1 & 10.5 & 10.5 & 21.0 & 4.0 & 1.0 & 240.0 & 0.2 & 240.0 \\
\hline 6 & 6.1 & 8.6 & 14.0 & 24.0 & 3.6 & 13.8 & 139.0 & 0.1 & 139.0 \\
\hline 7 & 4.9 & 15.7 & 10.5 & 28.0 & 3.4 & 12.0 & 245.0 & 0.6 & 245.0 \\
\hline 8 & 3.6 & 7.0 & 8.8 & 66.0 & 5.5 & 49.3 & 215.0 & 0.7 & 215.0 \\
\hline
\end{tabular}

The slope length of the undisturbed segment was calculated by deducting the slope length of the bed and riser segments from the total slope length. A length of $1.0 \mathrm{~m}$ was used to replace the calculation result of plot 5 , whose calculated value was less than 0 .

Table 3. Summary of segments $P$ factor value used in the modified SWAT model of the terraced field in Franklin County, Kansas.

\begin{tabular}{ccccc}
\hline & \multirow{2}{*}{$\begin{array}{c}\text { Area } \\
\text { Plot }\end{array}$} & \multicolumn{3}{c}{ P Factor Value } \\
\cline { 3 - 5 } & 0.40 & Original & Bed & Riser \\
\hline 2 & 0.49 & 0.50 & 0.50 & 0.80 \\
4 & 0.56 & 0.50 & 0.60 & 0.60 \\
5 & 0.39 & 0.50 & 0.60 & 0.60 \\
6 & 0.76 & 0.50 & 0.60 & 0.70 \\
7 & 1.46 & 0.50 & 0.70 & 0.60 \\
8 & & & 0.50 & 0.60 \\
\hline
\end{tabular}

2003, and grain sorghum in 2004. Crop yield data recorded in bushels per acre were corrected to test weights and moisture of $56 \mathrm{lbs} \mathrm{bu}^{-1}$ at $12.5 \%$ moisture for grain sorghum and $60 \mathrm{lbs} \mathrm{bu}^{-1}$ at $15.5 \%$ moisture for soybean. Yield data were converted to $\mathrm{kg} \mathrm{ha}^{-1}$ of dry weight for comparison with model estimates.

\section{Model SeTUP}

In order to compare simulated results and measured data from each plot, six SWAT models were parameterized for simulation (one model for each plot). These models were calibrated and validated separately. All of the plots were set to $100 \%$ terraced with all three kinds of segments (as shown in table 2). Detailed information of important field operations of each plot from 2000 to 2004 (i.e., planting, harvesting, and tillage dates) and applied amounts of fertilizer and herbicide, were specified in the management input file for each plot. The same management practices and corresponding dates were simulated for all segments of a plot.

The Manning's $\mathrm{n}$ for overland flow of all the segments in each plot was set to 0.03 . The drainage capacities (maximum volume of water that could be drained out of the terrace per day per ha) of all plots were set to $500 \mathrm{~m}^{3} \mathrm{~d}^{-1} \mathrm{ha}^{-1}$. This value was chosen because, based on personal observation, most runoff events could be drained out of the terrace plots in one day with the exception of events greater than approximately $50 \mathrm{~mm} \mathrm{~d}^{-1}$ (J. Kimball, Plant Science Technician, Kansas State University, East Central Experiment Field, personal communication, 2012). No minimum drainage trigger depth (normal depth) was set. The USLE_P factor values were selected based on the slope steepness of each segment using the value recommended by Wischmeier and Smith (1978) for contour cropping (table 3). The crop residue decomposition coefficient (rsdco_pl) was set to $0.01 \mathrm{~g} \mathrm{~g}^{-1}$ for grain sorghum and $0.03 \mathrm{~g} \mathrm{~g}^{-1}$ for soybean based on recommended values used in the Wind Erosion Prediction System model (Van Donk et al., 2008; Schomberg et al., 1994).

The complete simulation period was from 2000 to 2004, which included a one-year warm-up period (2000) followed by a runoff and sediment calibration and validation period during 2001 to 2004. Predicted drainage runoff and sediment from the channel of each plot and annual crop yields were compared to measured data to perform the calibration and validation.

\section{Model Calibration ANd VAlidation}

Event runoff and sediment loads from one plot of each crop management (plot 6 for TILL, 7 for NT/DB, and 8 for NT/SB) were used for calibration, while those from the other plot of each crop management (plot 5 for TILL, 2 for $\mathrm{NT} / \mathrm{DB}$, and 4 for NT/SB) were used for validation. If there was simulated runoff output during the previous day of the measured runoff event date, then the simulated runoff and sediment output of these two days were lumped to compare with the measured data. This is because only one measured event date was recorded at the end of each runoff event, even if that event lasted more than one day. Events that resulted from more than two days of rainfall (event day and the previous day) were eliminated from calibration because one single sample did not include sufficient information for comparison with simulated results. In addition, it is more likely that the sampler stopped sampling because the bottle was full. Annual crop yield data were used for calibrating the plant growth processes, which were critical for correct simulation of sediment yields. A three-stage calibration approach was adopted in this study.

The runoff calibration served as the first stage and relied on adjusting the soil available water capacity (SOL_AWC) of for each soil type and the curve number for average moisture conditions $\left(\mathrm{CN}_{\mathrm{II}}\right)$ for each of the different crop management systems. The initial value of $\mathrm{CN}_{\mathrm{II}}$ for all segments in each plot was 82 . The values of $\mathrm{CN}_{\mathrm{II}}$ for grain sorghum and soybean were adjusted for each management system in order to optimize the goodness-of-fit indicators, i.e., Nash-Sutcliffe model efficiency (NS), ratio of the root mean square error to the standard deviation of measured data (RSR), and percent bias (PBIAS), where NS was the prime consideration (Harmel et al., 2010; Maski et al., 2008; Moriasi et al., 2007). Runoff events of plot 8 were used for calibrating the SOL_AWC of SUM soil due to the large area of SUM soil in this plot, and plot 6 was used for adjusting the SOL_AWC of the EL soil. The $\mathrm{CN}_{\mathrm{II}}$ value following the harvest and kill operation in each plot was set two units greater than that of the growing crop, and the $\mathrm{CN}_{\mathrm{II}}$ values following tillage operations in the fall and prior to planting were set one unit less than the minimum value of the harvests' $\mathrm{CN}_{\mathrm{II}}$ for each crop. For example, if the $\mathrm{CN}_{\mathrm{II}}$ values were set to 74 and 80 at planting for grain sorghum and soybean, respectively, then the values for harvest and kill operation were $76(74+2)$ and $82(80+2)$ for grain 
sorghum and soybean, and the tillage $\mathrm{CN}_{\mathrm{II}}$ was set to 75 for both crops (minimum of 76 and 82 minus 1).

The second stage was the calibration of annual crop yields. Crop growth stress factors were used to select parameters for crop yield calibration; temperature stress was the limiting factor for both grain sorghum and soybean growth, and sorghum was also constrained by nitrogen stress. Therefore, parameters affecting temperature and nitrogen stress were selected for calibrating both crops separately (table 6). The adjustment ranges of these parameters were selected based on published literature (Nair et al., 2011; Peacock, 1982; Yu et al., 2004). It should be noted that there were very limited crop yield data (nine for grain sorghum and six for soybean), and the main purpose of crop yield calibration was to better represent the plant growth processes of the plots. Therefore, no validation was performed for crop yield.

Sediment calibration was the last stage in this study. The simulated and measured sediment yields were compared for the same events as for runoff calibration. The crop minimum cover factor and the terrace sediment settling coefficient were selected as the target model parameters for sediment calibration. The satisfactory performance criteria, all based on event data, for the streamflow simulation were NS $>0.50$, RSR $<0.70$, and PBIAS within $\pm 25 \%$ (Moriasi et al., 2007). The NS and RSR criteria for sediment were the same, but the range of PBIAS was expanded to $\pm 50 \%$, again based on recommendations by Moriasi et al. (2007).

\section{RESULTS AND DISCUSSION RUNOFF}

As the first calibration stage in this study, $\mathrm{CN}_{\mathrm{II}}$ for different crop management and the soil available water content were adjusted to produce satisfactory runoff simulation (table 4). The calibrated $\mathrm{CN}_{\mathrm{II}}$ values for both crops ranged between 78 and 86 and were representative of the hydrological soil group $\mathrm{C}$ of both soils $\left(\mathrm{CN}_{\mathrm{II}}\right.$ range of 76 to 88$)$ (Neitsch et al., 2011). Best-fit soil available water capacities were 0.03 and 0.04 larger than the baseline values for SUM and EL soils. The average values of the available water capacities for the whole soil profile were 0.18 and 0.17 for SUM and EL, respectively, which agreed well with published values of 0.17 for silty clay loams (Saxton and Rawls, 2006) and were close to the value of 0.21 indicated in the SWAT theoretical documentation for clay soils (Neitsch et al., 2011).

Figure 8 presents an event-based graphical comparison between the measured runoff depth and the runoff depth predicted by the modified SWAT model. Figures $8 \mathrm{a}$ and $8 \mathrm{~b}$ compare the runoff depth for different crop management combinations for the calibration and validation plots (same markers are used for same management in figs. 8a and $8 \mathrm{~b}$ ), while figures $8 \mathrm{c}$ and $8 \mathrm{~d}$ compare simulated and measured runoff on plots where the runoff values from either the calibration or validation plots were combined on an area basis. These figures show that the new model was able to simulate the runoff for most events. The data points distribute around the 1:1 line across the whole range of values.

The goodness-of-fit indicators used to compare model results with measured data give a quantitative indication of the model's performance (table 5). The average values of NS and RSR for the validation plots were similar to those obtained for the calibration plots. The model's performance in runoff simulation was satisfactory for all the plots and under different crop management (table 5). The consistent performance of the calibration and validation results indicates that fieldscale simulation of runoff from terraces by the incorporated terrace algorithm was satisfactory at this site.

\section{CROP Yield}

The baseline simulation after runoff calibration indicated that the crop yield of soybean was consistently greater than the measured data, and temperature and nitrogen were the main factors affecting plant growth for both crops. Therefore, BIO_E and HI were adjusted to calibrate average yields for both crops. The minimum and optimal temperatures for plant growth (table 6) were adjusted to reproduce the crop yield variations between years. Following Nair et al. (2011), BIO_E was reduced from 25 to 20 for soybean and from 33.5 to 30 for grain sorghum. HI was adjusted to 0.22 , which was lower than the value of 0.27 obtained by Nair et al. (2011), who also reduced the maximum potential LAI in decreasing the soybean yield and somehow obtained the higher HI. The normal fraction $\mathrm{N}$ in sorghum grain was reduced by $30 \%$ to compensate for the nitrogen stress for grain sorghum. This adjustment was close to the calibrated percentage change $(-26 \%)$ of winter wheat from Nair et al. (2011). The fraction of porosity for anion exclusion was also decreased from 0.5 to 0.3 to keep nitrate from leaking out of soil profile.

The crop rotation on all plots from 2000 to 2004 was grain sorghum (even years) and soybean (odd years). Figure 9 compares the annual measured and simulated crop yields for the different crop management systems. In general, annual crop yield variation in both grain sorghum and soybean was simulated by the model. The average predicted crop yields were $5216 \mathrm{~kg} \mathrm{ha}^{-1}$ for grain sorghum and

Table 4. Best-fit parameters for runoff calibration of the modified SWAT model of the terraced field in Franklin County, Kansas.

\begin{tabular}{ccc}
\hline Parameter ${ }^{[a]}$ & Physical Meaning & Fitted Value \\
\hline CN $_{\text {II }}$ TILL plant G. sorghum & $\mathrm{CN}_{\text {II }}$ for TILL after planting grain sorghum & 78 \\
$\mathrm{CN}_{\text {II }}$ NT/DB plant G. sorghum & $\mathrm{CN}_{\text {II }}$ for NT/DB after planting grain sorghum & 78 \\
$\mathrm{CN}_{\text {II }}$ NT/SB plant G. sorghum & $\mathrm{CN}_{\text {II }}$ for NT/SB after planting grain sorghum & 83 \\
$\mathrm{CN}_{\text {III TILL plant soybean }}$ & $\mathrm{CN}_{\text {II }}$ for TILL after planting soybean & 80 \\
$\mathrm{CN}_{\text {II }}$ NT/DB plant soybean & $\mathrm{CN}_{\text {II }}$ for NT/DB after planting soybean & 86 \\
$\mathrm{CN}_{\text {II }}$ NT/SB plant soybean & $\mathrm{CN}_{\text {II }}$ for NT/SB after planting soybean & 82 \\
SOL_AWC SUM & Available water capacity of the SUM soil & +0.03 \\
SOL_AWC EL & Available water capacity of the EL soil & +0.04 \\
\hline
\end{tabular}

[a] $\mathrm{TILL}=$ fall chisel tillage, spring cultivation; NT/DB = no-till, spring deep-banded applications; and NT/SB = no-till, spring surface-broadcast.

[b] Fitted values with plus (+) signs represent the relative change of the baseline value. 

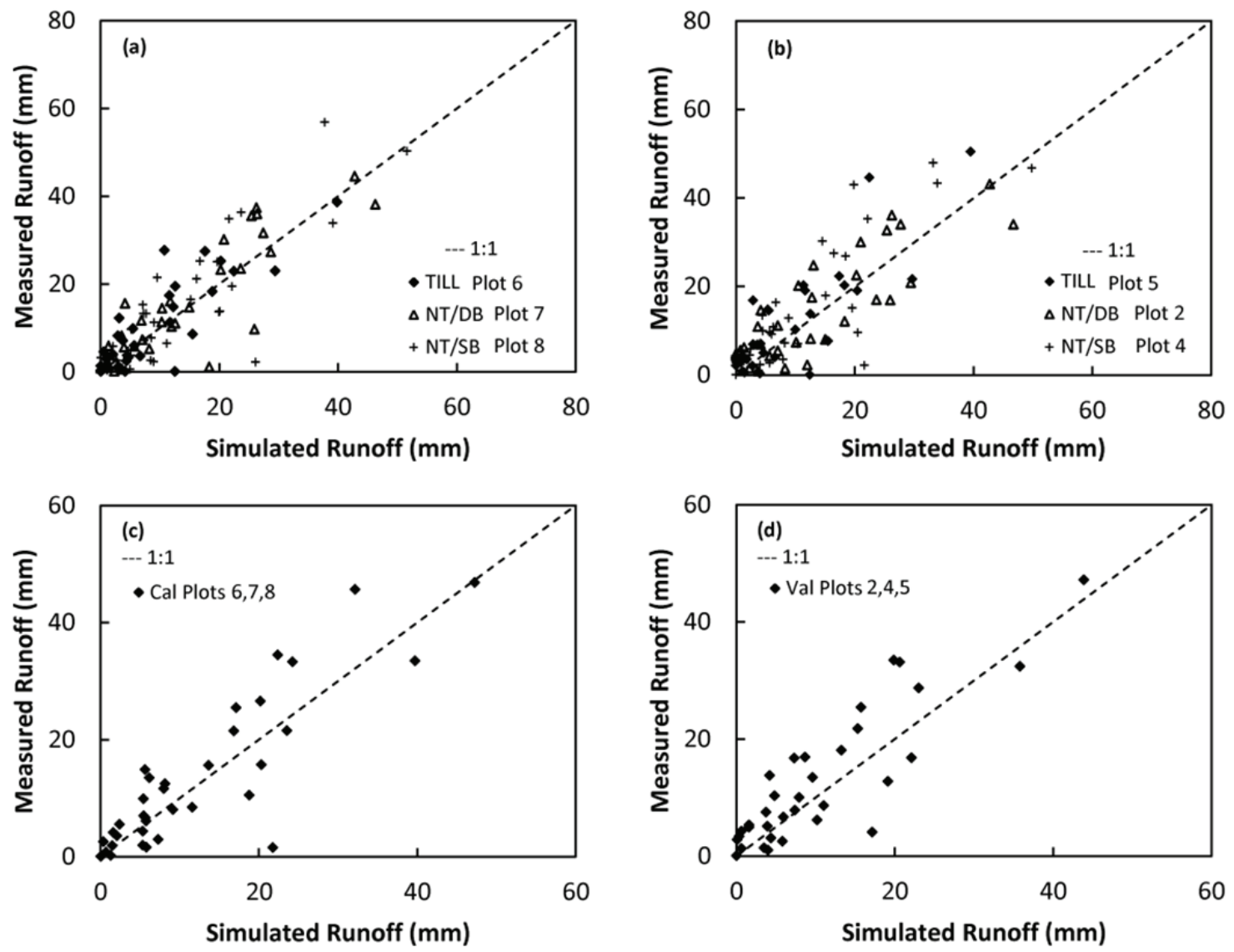

Figure 8. Event runoff depth comparison of the calibrated and validation plots: (a) runoff depth of calibration plots, (b) runoff depth of validation plots, (c) average runoff depth of calibration plots, and (d) average runoff depth of validation plots. Cal $=$ calibration, Val $=$ validation.

Table 5. Goodness-of-fit results for event runoff depth for the terraced field in Franklin County, Kansas.

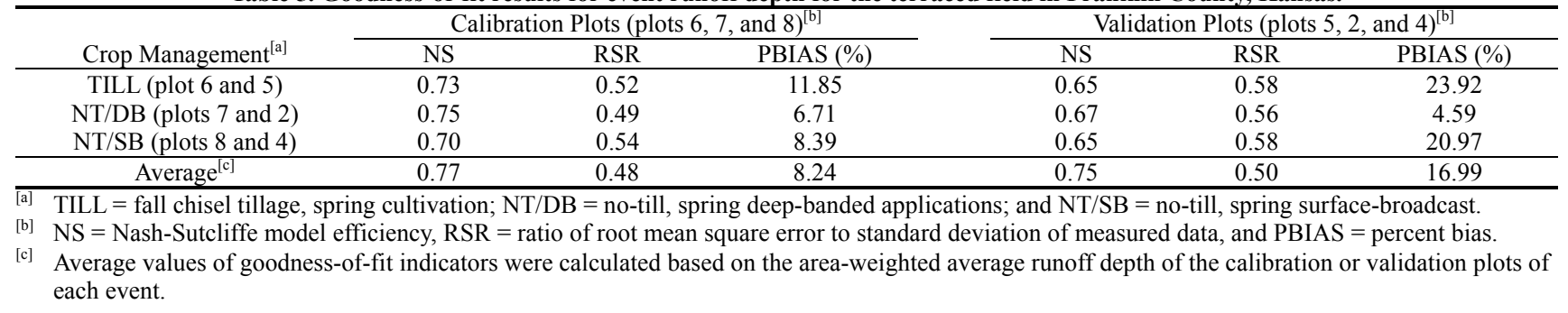

Table 6. Best-fit parameters for crop yield calibration of the modified SWAT model of the terraced field in Franklin County, Kansas.

\begin{tabular}{ccc}
\hline Parameter & Physical Meaning & Fitted Value ${ }^{[a]}$ \\
\hline BIO_E soybean & Plant radiation use efficiency for soybean $\left(\mathrm{MJ} \mathrm{m}^{-2}\right)$ & 20 \\
HI soybean & Harvest index for soybean & 0.22 \\
T_base soybean & Minimum temperature for soybean growth $\left({ }^{\circ} \mathrm{C}\right)$ & 12 \\
BIO_E G.sorghum & Plant radiation use efficiency for grain sorghum & 30 \\
T_base G.sorghum & Minimum temperature for grain sorghum growth $\left({ }^{\circ} \mathrm{C}\right)$ & 6 \\
T_op G.sorghum & Optimal temperature for grain sorghum growth $\left({ }^{\circ} \mathrm{C}\right)$ & 26 \\
PLTNFR G.sorghum & Normal fraction of N in grain sorghum biomass at all living stages & $-30 \%$ \\
anion_excl & Fraction of porosity from which anions are excluded & 0.3 \\
\hline a] & Fitted &
\end{tabular}

[a] Fitted value in percentage represents the relative change of the original value used in SWAT.

$1683 \mathrm{~kg} \mathrm{ha}^{-1}$ for soybean, which were $0.21 \%$ and $0.41 \%$ lower than the measured data. The small percent bias values for both crops and the graph (fig. 9) indicated that simulated and measured biomass were in agreement, which was critical for sediment simulation.

\section{SEDIMENT}

Sediment calibration was the third and final stage of the simulation. The terrace sediment settling coefficient
(TRC_STLR_CO) and the minimum USLE C factor were adjusted to represent the terrace storage effect and the crop cover protecting against erosion. Best fit USLE-C min values were all between 0.08 and 0.15 (table 7), a relatively small interval given the variability that can exist in residues depending on moisture and temperature. Average minimum values for the tilled and no-till systems ( 0.13 and 0.11 , respectively) were very close, as were the average minimum values for soybean and sorghum ( 0.13 and 0.11 , respectively). 


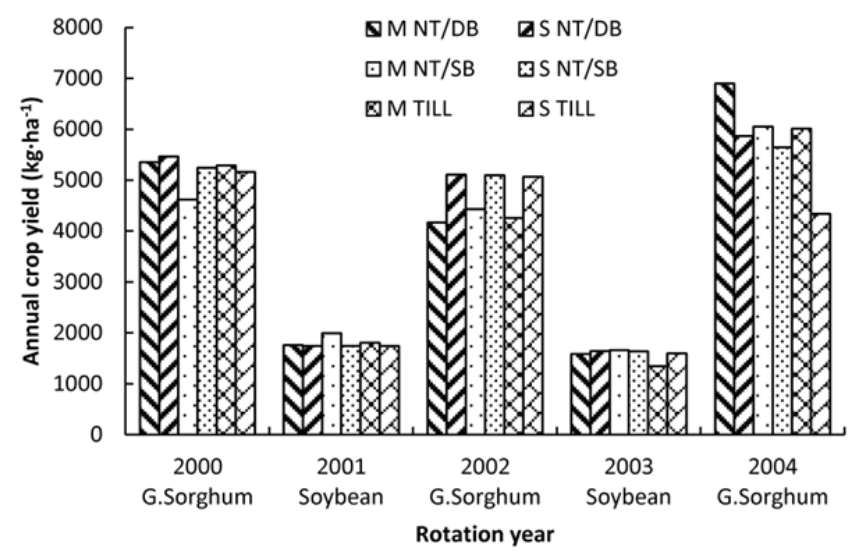

Figure 9. Crop yield comparison for the three crop management systems at the Franklin County, Kansas, site: $M=$ measured crop yields, $\mathrm{S}=$ simulated crop yields. $\mathrm{TILL}=$ fall chisel tillage, spring cultivation, NT/DB = no-till, spring deep-banded applications, and NT/SB $=$ notill, spring surface-broadcast.

Figure 10 illustrates the plot-specific and three-plot average event sediment yield comparison of simulated and measured results (same markers are used for same management in figs. 10a and 10b). Similar to the runoff simulation, the points were distributed around the 1:1 line, yet with a larger deviation from that line. As expected, the sediment yield was higher under tilled conditions than from the no-till plots. Tillage, which increases the porosity in soil, destroys the residue cover of the ground and leaves the soil more vulnerable to erosion. Another reason for the high sediment yield rate in plot 5 (validation plot with TILL management) was the slope steepness, which was the highest of all the plots.

Table 8 summarizes the event sediment yield model performance results under different crop management. Performance results indicated that the model performed well in simulating average sediment yields on the calibration plots, with an average NS of 0.77 . The average NS and RSR of the validation plots were lower but met the performance criteria.

The model produced satisfactory results for all individual calibration plots and tilled validation plot. For no-till validation plots (plots 2 and 4), the sediment yield simulation was not good enough to meet the standard. The difference in performance between the calibration and validation no-till plots was possibly caused by differences in soils and geomorphology. For example, plot 8 was mapped as the summit soil at the footslope, which was flatter and larger, whereas plot 4 was mapped as the Eram-Lebo complex and was located on the sideslope, which was steeper and smaller. Additionally, sediment yields on the validation no-till plots were smaller than on the calibration plots, i.e., the average measured sediment on validation plot NT/SB plot 4 $\left(0.43 \mathrm{Mg} \mathrm{ha}^{-1}\right.$ year $\left.^{-1}\right)$ was about $3 / 4$ of that on the corresponding calibration plot (plot $8,0.59 \mathrm{Mg} \mathrm{ha}^{-1}$ year $^{-1}$ ), and the value of soybean years of NT/DB plot $2\left(0.28 \mathrm{Mg} \mathrm{ha}^{-1}\right.$ year $\left.{ }^{-1}\right)$ was about $2 / 3$ of that on plot $7\left(0.41 \mathrm{Mg} \mathrm{ha}^{-1}\right.$ year $\left.^{-1}\right)$. These yields were also much lower, as expected, than those from tilled plots $\left(1.23 \mathrm{Mg} \mathrm{ha}^{-1}\right.$ year $\left.^{-1}\right)$. Low sediment yields are typically very difficult to measure accurately with an automatic sampler. These results indicate that the error inherent in the measured data should be taken into consideration when evaluating the performance of the model.

In summary, although the model's performance on the validation no-till plots was less consistent than on the other plots, the performance on the other plots and the average performance met the criteria in simulating sediment yield, which gives confidence that the new version of SWAT correctly predicted erosion and soil loss. In this calculation, soil properties were obtained from the NRCS web soil survey. Measurement of site-specific soil characteristics (e.g., soil depth, available water content, bulk density, and $K_{\text {sat }}$ ) for each plot could improve the accuracy of simulated sediment yields.

This version of SWAT adds to the original code and provides a process-based ability to assess terrace effects. In the original SWAT model, these effects were simulated by adjusting the slope length and USLE_P factor. Given that soil loss calculated with MUSLE is directly proportional to these two factors, the changes in slope length and USLE_P factor essentially control the resulting sediment load, excluding the channel sediment transport processes that occur between the edge-of-field and the watershed outlet. Thus, the reductions in sediment load obtained after adjustment of these parameters are likely to be more or less proportional to the user-specified reductions in these parameters values. Similarly, adjustment of the curve number could be used to simulate a reduction in runoff caused by the ponding of water in the terrace. However, there are few data to use as a basis for the $\mathrm{CN}$ reduction. The proposed process-based code gives the ability to estimate soil loss and flow reduction from terraces without making any assumption about the expected reduction. Additionally, and not tested in this case study, the effects on $\mathrm{N}$ and $\mathrm{P}$ fate and transport can be simulated. In this study, we have not compared the model results to those obtained in the field with the original code. The goal was to ensure that the model was working properly and that correct flow and sediment loads were obtained at the outlet of each terrace. Additional work will include undertaking that comparison, using a yet unidentified da-

Table 7. Best-fit parameters for sediment calibration of the modified SWAT model of the terraced field in Franklin County, Kansas.

\begin{tabular}{ccc}
\hline Parameter $^{[a]}$ & Physical Meaning & Fitted Value \\
\hline USLE-C $\min$ TILL G.sorghum & Minimum value of USLE C factor for TILL with grain sorghum & 0.12 \\
USLE-C min TILL soybean & Minimum value of USLE C factor for TILL with soybean & 0.13 \\
USLE-C min NT/DB G.sorghum & Minimum value of USLE C factor for NT/DB with grain sorghum & 0.10 \\
USLE-C min NT/DB soybean & Minimum value of USLE C factor for NT/DB with soybean & 0.08 \\
USLE-C $\min$ NT/SB G.sorghum & Minimum value of USLE C factor for NT/SB with grain sorghum & 0.10 \\
USLE-C min NT/SB soybean & Minimum value of USLE C factor for NT/SB with soybean & 0.15 \\
TRC_STLR_CO TILL & Terrace sediment settling coefficient for TILL & 0.20 \\
TRC_STLR_CO NT/DB & Terrace sediment settling coefficient for NT/DB & 0.24 \\
TRC_STLR_CO NT/SB & Terrace sediment settling coefficient for NT/SB & 0.20 \\
\hline
\end{tabular}

[a] TILL = fall chisel tillage, spring cultivation; NT/DB = no-till, spring deep-banded applications; and NT/SB = no-till, spring surface-broadcast. 

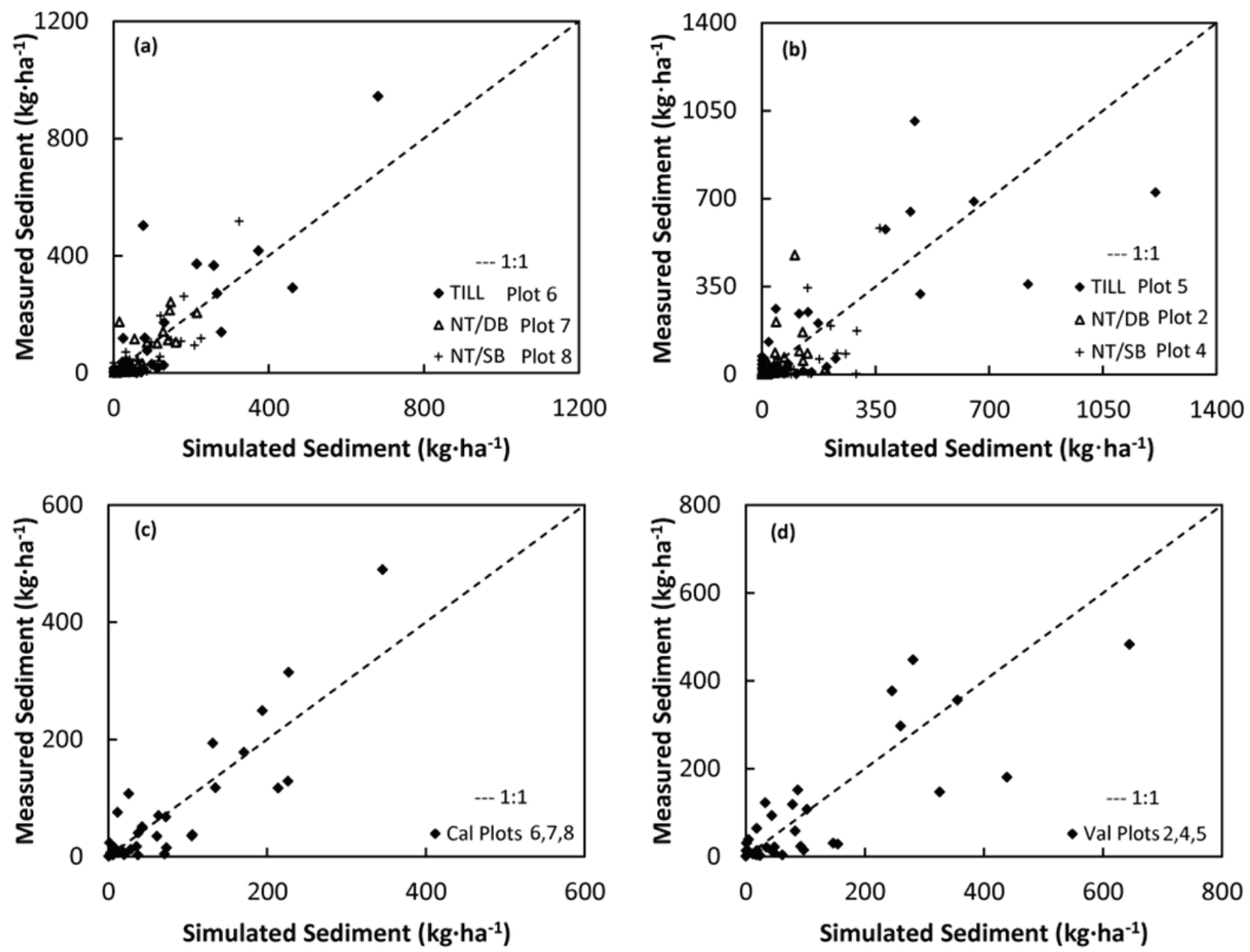

Figure 10. Event sediment yield comparison for calibration and validation: (a) sediment yield of calibration plots, (b) sediment yield of validation plots, (c) average sediment yield of calibration plots, and (d) average sediment yield of validation plots. Cal $=$ calibration, Val $=$ validation. taset at the outlet of a small terraced watershed.

Table 8. Goodness-of-fit results for event sediment yield at the Franklin County, Kansas, site.

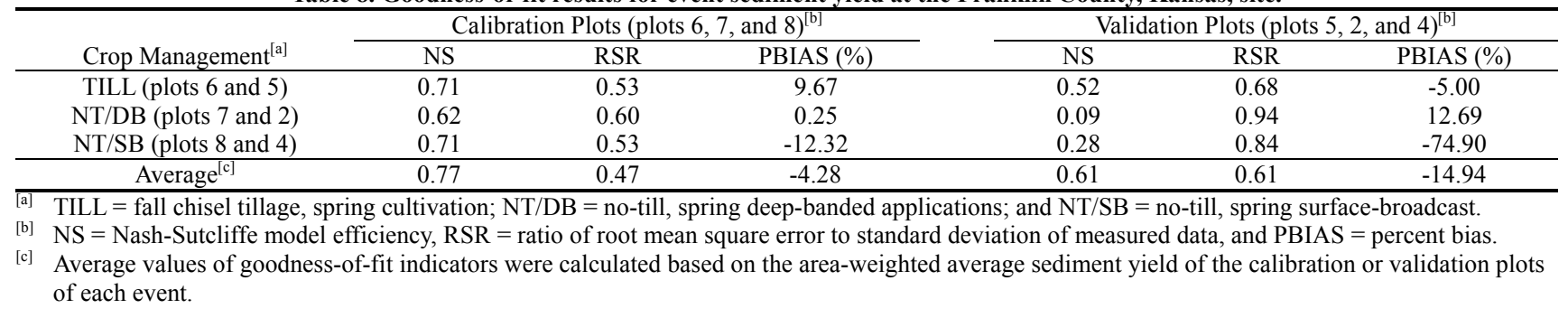

\section{SUMMARY AND CONCLUSIONS}

In this study, a process-based terrace algorithm was developed in SWAT (version 2009) to simulate the environmental effects of different terrace practices at watershed scale. The algorithm was incorporated and activated in SWAT at the HRU level, where terraces are described as a fraction of the HRU area and divided into three segments. The runoff, sediment, $\mathrm{N}$ and $\mathrm{P}$, soil system, and plant growth were simulated separately on each segment. Algorithms for simulating the terrace storage effects were also developed, i.e., additional infiltration and evaporation; sediment, N, and $\mathrm{P}$ settling; and channel erosion. Terrace drainage and overland flow were incorporated into the model.

The new version of SWAT was evaluated using annual crop yield and event runoff and sediment data sets collected at a six-plot terraced field with different crop managements and soils in southeast Franklin County, Kansas. The runoff simulation was satisfactory (NS always $>0.6$ ) at both the single plot level and across the average of three plots for both the calibration and validation simulations. The model also performed satisfactorily in simulating sediment transport for all the individual calibration plots and for the tilled validation plot. However, the validation results for the no-till plots were less consistent. The calibration results proved the feasibility of simulating runoff and sediment yield from terraced fields using the modified SWAT model. However, the sediment results for the no-till plots underscore the need to conduct additional calibration and validation research with the new terrace algorithms across a variety of soil and topography conditions.

This modification adds flexibility and functionality in simulating terraces in SWAT2009 (and later versions). This new model provides an alternative to the traditional P-factor and slope length method for assessing terrace ef- 
fects by allowing evaluation of terrace effects in fully or partly terraced HRUs, as well as simulating terrace effects on crop yields, infiltration, $\mathrm{N}$ and $\mathrm{P}$ loss, and the overall effect of terraces on streamflow in a watershed. The importance of the effect of terraces on streamflow and water supplies cannot be underestimated at a time when droughts are becoming more frequent. In drought-prone areas where conservation terraces could have an impact on streamflow (Twombly et al., 2008; Irmak et al., 2006), a watershedscale model that integrates all the water-related processes should bring objective assessment to the development of a water resources management plan.

Currently, the HRU method used in the standard SWAT model does not account for landscape position (Arnold et al., 2010). However, the forthcoming landscape version of SWAT (Arnold et al., 2010; Bosch et al., 2010), which takes into account the spatial distribution of different landscape elements, should provide additional options to simulate the interactions between the different elements of a terraced slope. The terrace routines developed here can be integrated within that version. With this capability, it should be possible to better assess the effect that cultivation of the steeper parts of a slope has on the footslope area, with and without terraces. Other than the SWAT model, the commonly used equations and parameters in the terrace algorithm and the self-contained simulation structure make the terrace routines portable and enable their integration into other hydrological models, such as APEX. Future development of a GIS tool to determine the terrace parameter values for a watershed would be needed to effectively apply SWAT and other hydrological models at larger spatial scales.

\section{ACKNOWLEDGEMENTS}

This article is sponsored by the Chinese National Technology Support Project entitled: "The integration of key technologies and demonstration of the soil and water conservation and efficient agriculture in the gullies rolling loess area" (2011BAD31B05) and Sub-task of Major State Science and Technology Special Project entitled: "Water Pollution Control and Treatment" (2009ZX07212-002-00302). Mr. Hui Shao gratefully acknowledges the China Scholarship Council for supporting his study trip to the U.S.

\section{REFERENCES}

Alberts, E. E., G. E. Schuman, and R. E. Burwell. 1978. Seasonal runoff losses of nitrogen and phosphorus from Missouri Valley loess watersheds. J. Environ. Qual. 7(2): 203-208.

Arabi, M., J. R. Frankenberger, B. A. Engel, and J. G. Arnold. 2008. Representation of agricultural conservation practices with SWAT. Hydrol. Proc. 22(16): 3042-3055.

Arnold, J. G., and N. Fohrer. 2005. SWAT2000: Current capabilities and research opportunities in applied watershed modelling. Hydrol. Proc. 19(3): 563-572.

Arnold, J. G., P. M. Allen, M. Volk, J. R. Williams, and D. D. Bosch. 2010. Assessment of different representations of spatial variability on SWAT model performance. Trans. ASABE 53(5): 1433-1443.

Arnold, J. G., D. N. Moriasi, P. W. Gassman, K. C. Abbaspour, M. J.
White, R. Srinivasan, C. Santhi, R. D. Harmel, A. van Griensven, M. W. Van Liew, N. Kannan, and M. K. Jha. 2012. SWAT: Model use, calibration, and validation. Trans. ASABE 55(4): 1491-1508.

Bosch, D. D., J. G. Arnold., M. Volk, and P. M. Allen. 2010. Simulation of a low-gradient Coastal Plain watershed using the SWAT landscape model. Trans. ASABE 53(5): 1445-1456.

Bracmort, K. S., M. Arabi, J. R. Frankenberger, B. A. Engel, and J. G. Arnold. 2006. Modeling long-term water quality impact of structural BMPs. Trans. ASABE 49(2): 367-374.

Csuros, M. 1997. Environmental Sampling and Analysis Lab Manual. Boca Raton, Fla.: CRC Press.

Dorren, L., and F. Rey. 2004. A review of the effect of terracing on erosion. Grenoble, France: Cemagref. Available at: http://eusoils.jrc.ec.europa.eu/projects/scape/transf/Dorren_Rey. pdf. Accessed 25 October 2012.

Du, B., J. G. Arnold, A. Saleh, and D. B. Jaynes. 2005. Development and application of SWAT to landscapes with tiles and potholes. Trans. ASAE 48(3): 1121-1133.

Easton, Z. M., D. R. Fuka, M. T. Walter, D. M. Cowan, E. M. Schneiderman, and T. S. Steenhuis. 2008. Re-conceptualizing the Soil and Water Assessment tool (SWAT) model to predict runoff from variable source areas. J. Hydrol. 348(3-4): 279-291.

Gassman, P. W., M. R. Reyes, C. H. Green, and J. G. Arnold. 2007. The Soil and Water Assessment Tool: Historical development, applications, and future research directions. Trans. ASABE 50(4): 1211-1250.

Gassman, P. W., J. A. Tisl, E. A. Palas, C. L. Fields, T. M. Isenhart, K. E. Schilling, C. F. Wolter, L. S. Seigley, and M. J. Helmers. 2010. Conservation practice establishment in two northeast Iowa watersheds: Strategies, water quality implications, and lessons learned. J. Soil and Water Cons. 65(6): 381-392.

Grant, D. M., and B. D. Dawson. 2001. Isco Open-Channel Flow Measurement Handbook. 5th ed. Lincoln, Neb.: Isco, Inc.

Harmel, R. D., P. K. Smith, and K. W. Migliaccio. 2010. Modifying goodness-of-fit indicators to incorporate both measurement and model uncertainty in model calibration and validation. Trans. $A S A B E$ 51(1): 55-63.

Irmak, A., D. L. Martin, J. K. Koelliker, and D. E. Eisenhauer. 2006. Modeling the effects of terracing on water supplies in the Medicine Creek. ASABE Paper No. 062291. St. Joseph, Mich.: ASABE.

Jeong, J., N. Kannan, J. G. Arnold, R. Glick, L. Gosselink, R. Srinivasan, and R. D. Harmel. 2011a. Development of sub-daily erosion and sediment transport algorithms for SWAT. Trans. ASABE 54(5): 1685-1691.

Jeong, J., C. Santhi, J. G. Arnold, R. Srinivasan, S. Pradhan, and K. Flynn. 2011b. Development of algorithms for modeling onsite wastewater systems within SWAT. Trans. ASABE 54(5): 16931704.

Laflen, J. M., and W. C. Moldenhauer. 2003. Pioneering soil erosion prediction: The USLE story. Special Publication No. 1. Beijing, China: World Association of Soil and Water Conservation.

Maski, D., K. R. Mankin, K. A. Janssen, P. Tuppad, and G. M. Pierzynski. 2008. Modeling runoff and sediment yields from combined in-field crop practices using the Soil and Water Assessment Tool. J. Soil and Water Cons. 63(4): 193-203.

Mathews, L. 2012. National Agricultural Imagery Program (NAIP) information sheet, June 2012. Washington, D.C.: USDA Farm Service Agency. Available at: www.fsa.usda.gov/Internet/FSA File/naip 2012 final.pdf. Accessed 6 September 2013.

Moriasi, D. N., J. G. Arnold, M. W. Van Liew, R. L. Bingner, R. D. Harmel, and T. L. Veith. 2007. Model evaluation guidelines for systematic quantification of accuracy in watershed simulations. Trans. ASABE 50(3): 885-900.

Moriasi, D. N., J. G. Arnold, G. G. Vazquez-Amábile, B. A. Engel, 
and C. G. Rossi. 2009. Incorporation of a new shallow water table depth algorithm into SWAT2005. Trans. ASABE 52(3): 771-784.

Moriasi, D. N., J. G. Arnold, G. G. Vazquez-Amábile, and B. A. Engel. 2011. Shallow water table depth algorithms in SWAT: Recent developments. Trans. ASABE 54(5): 1705-1711.

Nair, S. S., K. W. King, J. D. Witter, B. L. Sohngen, and N. R. Fausey. 2011. Importance of crop yield in calibrating watershed water quality simulation tools. J. American Water Resour. Assoc. 47(6): 1285-1297.

Narasimhan, B., P. M. Allen, R. Srinivasan, S. T. Bednarz, J. Arnold, and J. A. Dunbar. 2007. Streambank erosion and best management practice simulation using SWAT. ASABE Paper No 701P0207. St. Joseph, Mich.: ASABE.

Narasimhan, B., R. Srinivasan, S. T. Bednarz, M. R. Ernst, and P. M. Allen. 2010. A comprehensive modeling approach for reservoir water quality assessment and management due to point and nonpoint source pollution. Trans. ASABE 53(5): 1605-1617.

Neibling, W. H., and A. L. Thompson. 1992. Terrace design affects inter-terrace sheet and rill erosion. Trans. ASAE 35(5): 14731481.

Neitsch, S. L., J. G. Arnold, J. R. Kiniry, and J. R. Williams. 2011. Soil and Water Assessment Tool Theoretical Documentation. Version 2009. TR-406. College Station, Texas: Texas A\&M University System.

Panuska, J. C. 1999. Estimating phosphorus concentrations following alum treatment using apparent settling velocity. $J$. Lake and Reservoir Mgmt. 15(1): 28-38.

Peacock, J. M. 1982. Response and tolerance of sorghum to temperature stress. In Proc. Intl. Symp. on Sorghum: Sorghum in the Eighties, 143-159. Patancheru, India: International Crops Research Institute for the Semi-Arid Tropics (ICRISAT).

Saxton, K. E., and W. J. Rawls. 2006. Soil water characteristic estimates by texture and organic matter for hydrologic solutions. SSSA J. 70(5): 1569-1578.

Schomberg, H. H., J. L. Steiner, and P. W. Unger. 1994. Decomposition and nitrogen dynamics of crop residues: Residue quality and water effects. SSSA J. 58(2): 372-381.

Shao, H., C. Baffaut, and J. E. Gao. 2012. A process-based method for evaluating terrace runoff and sediment yield. ASABE Paper No. 121341006. St. Joseph, Mich.: ASABE.

Shi, S. X. 1996. Impact of measures of afforestation with engineering preparation to strengthening rainfall infiltration and reducing sediment. J. Soil Erosion and Soil and Water Cons. 2(4): 54-59 (in Chinese).

Twombly, B. J., D. E. Eisenhauer, D. L. Martin, and T. G. Smith. 2008. Field-scale water balance modeling of conservation terraces in the Republican River basin. ASABE Paper No. 085160. St. Joseph, Mich.: ASABE.

Van Dijk, A. I. J. M., and L. A. Bruijnzeel. 2004a. Runoff and soil loss from bench terraces: 1 . An event-based model of rainfall infiltration and surface runoff. European J. Soil Sci. 55(2): 299316.

Van Dijk, A. I. J. M., and L. A. Bruijnzeel. 2004b. Runoff and soil loss from bench terraces: 2. An event-based erosion process model. European J. Soil Sci. 55(2): 317-334.

Van Donk, S. J., S. D. Merrill, D. L. Tanaka, and J. M. Krupinsky. 2008. Crop residue in North Dakota: Measured and simulated by the Wind Erosion Prediction System. Trans. ASABE 51(5): 1623-1632.

Waidler, D., M. White, E. Steglich, C. A. Jones, and R. Srinivasan. 2011. Conservation practice modeling guide for SWAT and APEX. TR-399. College Station, Texas: Texas A\&M University System.

Wang, P., K. Q. Wang, T. X. Li, and Y. J. Li. 2011. Regulation effects of reverse-slope level terrace on the runoff and sediment yield in sloping farmland. Chinese J. Applied Ecol. 22(5): 12611267 (in Chinese).

Williams, J. R. 1995. The EPIC model. In Computer Models of Watershed Hydrology, 909-1000. V. P. Singh, ed. Highlands Ranch, Colo.: Water Resources Publications.

Williams, J. R., J. G. Arnold, J. R. Kiniry, P. W. Gassman, and C. H. Green. 2008. History of model development at Temple, Texas. Hydrol. Sci. J. 53(5): 948-960.

Wischmeier, W. H., and D. D. Smith. 1978. Predicting rainfall erosion losses: A guide to conservation planning. Agriculture Handbook 537. Washington, D.C.: USDA.

Yu, J., M. R. Tuinstraa, M. M. Claassena, W. B. Gordona, and M. D. Wittb. 2004. Analysis of cold tolerance in sorghum under controlled environment conditions. Field Crops Research 85(1): 21-30.

Zeimen, M. B., K. A. Janssen, D. W. Sweeney, G. M. Pierzynski, K. R. Mankin, D. L. Devlin, D. L. Regehr, M. R. Langemeier, and K. A. McVay. 2006. Combining management practices to reduce sediment, nutrients, and herbicides in runoff. J. Soil and Water Cons. 61(5): 258-267. 